7. FISHER, H.I. 1968. The "two-egg clutch" in the Laysan Albatross. Auk 85: 134-136.

8. FRY, D.M. and C.K. TOONE. 1981. DDTinduced feminization of gull embryos. Science 213: 992-924.

9. HAYS, H. and M. LeCROY. 1971. Field criteria for determining incubation stage in eggs of the Common Tern. Wilson Bulletin 83: 425-429.

10. HUSSELL, D.J.T. and J.K. WOODFORD. 1965. Piping Plover's nests containing eight eggs. Wilson Bulletin 77: 294.

11. MCNICHOLL, M. K. 1971. The breeding biology and ecology of Forster's Tern (Sterna forsteri) at Delta, Manitoba. M. Sc. Thesis, University of Manitoba, Winnipeg.

12. MCNICHOLL, M.K., P.E. LOWTHER, and J.A. HALL. 2001. Forster's Tern (Sterna forsteri). In The Birds of North America, No. 595 (A. Poole and F. Gill, eds.). The Birds of North America, Inc. Philadelphia, PA.

13. PENLAND, S. 1981. Natural history of the Caspian Tern in Grays Harbor, Washington. Murrelet 62: 66-72.

14. RICE, D.W., and K.W. KENYON. 1962. Breeding cycles and behavior of Laysan and Black-footed albatrosses. Auk 79: 517-567.
15. ROCKWELL, R.B. 1911. Notes on the nesting of the Forster's and Black Terns in Colorado. Condor 13: 57-63.

16. ROTHSTEIN, S.I. 1993. An experimental test of the Hamilton-Orians hypothesis for the origin of avian brood parasitism. Condor 95: 1000-1005.

17. SEALY, S.G. 1976. Biology of nesting Ancient Murrelets. Condor 78: 294-306.

18. SHEALER, D.A., and J.G. ZUROCHAK. 1995. Three extremely large clutches of Roseate Tern eggs in the Caribbean. Colonial Waterbirds 18: 105-107.

19. SNOW, B. 1960. The breeding biology of the Shag Phalacrocorax aristotelis on the island of Lundy, Bristol Channel. Ibis 102: 554-575.

20. SORENSON, M.D. 1995. Evidence of conspecific nest parasitism and egg discrimination in the Sora. Condor 97: 819-821.

21. TRUBRIDGE, M. 1980. Common Gull rolling eggs from adjacent nest into own. British Birds 73: 222-223.

22. WARHAM, J. 1962. The biology of the Giant Petrel Macronectes giganteus. Auk 79: 139-160.

23. WESTERKOV, K. 1950. Methods for determining the age of game bird eggs. Journal of Wildlife Management 14: 56-67.

\title{
PLUMBEOUS VIREO SIGHT RECORD FOR SASKATCHEWAN IN 2004
}

PHILIP S. TAYLOR, Canadian Wildlife Service, 115 Perimeter Road, Saskatoon, SK S7N 0X4, E-mail: phil.taylor @ec.gc.ca and REAL BISSON, Canadian Wildlife Service, Place Vincent Massey, 351 St. Joseph Blvd. Gatineau, Quebec K1A OH3

On 18 May 2004, the authors observed a bird fitting the description of a spring-plumaged Plumbeous Vireo at Val Marie, Saskatchewan. We watched the bird for over 25 minutes, starting at $0830 \mathrm{~h}$, in good light, using $10 \mathrm{X}$ binoculars and a variable power spotting scope $(15-45 X)$ from distances of 8-30 m, enabling us to check field marks several times and from different angles. We made field notes and used the Sibley Guide to Birds ${ }^{9}$ as a direct reference during our observations. The sky was clear, the wind calm, and the temperature $12^{\circ} \mathrm{C}$.

The bird was foraging in hybrid poplars approximately $15-20 \mathrm{~m}$ tall in a farmstead shelterbelt on the northeast corner of Val Marie, adjacent 
to the Frenchman River along Highway 18. The bird kept between 4 and $10 \mathrm{~m}$ from the ground, feeding among the mostly-leafless inner branches in early leaf-out stage, often near the trunk and only occasionally out to the branch tips. It did not feed in the top $3 \mathrm{~m}$ of the canopy. It moved about quietly and slowly, often perching on branches and did not move its tail (flick, bob or wag), in contrast to the rather nervous Yellow-rumped Warblers also present. The vireo would fly short distances, a few meters, to another tree where it continued feeding. We did not see or hear it vocalize.

The first field marks we saw were the conspicuous 'white spectacles,' general grey colouration and relatively short, dark bill, all suggesting one of the Solitary Vireo complex which includes the Plumbeous, Cassin's and Blue-headed Vireos. Both wing bars were evident, but thin, making the upper one somewhat less obvious. Closer investigation allowed us to see the even grey of the upper parts of the bird and confirm that there was no contrast between the head and back colour. The same grey colouration extended down the side of the head over the auriculars, and the lores were grey, contrasting with the white supraloral area. The throat was whitish, particularly when seen from below, but the contrast with the side of the head did not appear to be as sharply delineated as in a typical Blueheaded Vireo. The breast, belly, flanks and undertail coverts were whitish except for a small patch at the sides of the breast at the bend of the wing which was a dull, smudgy grey with no hint of yellow or buff. The outer edges of the flight feathers on the wings and tail were white and showed none of the buff or yellow colour expected on a Blue-headed or Cassin's Vireo. The tip of the primaries on the folded wing reached slightly past the tip of the undertail coverts. The eye was dark, and both the bill and legs were greyblack. These field marks agreed with the illustration in the Sibley field guide of a spring Plumbeous Vireo in worn adult plumage (page 348). We did not see the bird raise its tail as described by Sibley. ${ }^{9}$

In 1997, the American Ornithologists' Union officially divided the Solitary Vireo (Vireo solitarius) into three full species: Blue-headed Vireo (V. solitarius), Cassin's Vireo ( $V$. cassinii) and Plumbeous Vireo ( $V$. plumbeus). This split was based on molecular genetic studies that revealed significant divergence in mitochondrial DNA and allozymes within the Solitary Vireo complex. While the species have been illustrated separately in some field guides for some time, even before 1997 , identification of many individuals is difficult and requires caution.

Godfrey, in 1986, had no record of the Solitary (Plumbeous) Vireo (Vireo solitarius plumbeus) occurring in Canada either as a breeding subspecies or vagrant, however, since then several sightings have been reported for eastern Canada, all outside the breeding season: two fall records for Nova Scotia $2,5,11$ and two spring migration records for southern Ontario (M. Gosselin, Collection Manager, Canadian Museum of Nature, pers. comm., 8 Dec. 2005; M. Peck, Ornithology Technician, Royal Ontario Museum, pers. comm., $9 \mathrm{Dec}$. 2005).

There are no accepted Plumbeous Vireo records for the three prairie provinces (J. Hudon, Curator of Ornithology, Royal Alberta Museum, pers. comm., 8 Dec. 2005; R. Mooi, Curator of Zoology, Manitoba Museum 
of Man and Nature, pers. comm., 13 Dec. 2005; G. Sutter, Curator of Ornithology, Royal Saskatchewan Museum, pers. comm., 8 Dec. 2005). Part of the problem is that some records occurred prior to 1997 and the documentation is insufficient to assign the report to one of the three new vireo species. Chris Escott saw a Solitary Vireo singing on 13 June 1981 in the East Block of the Cypress Hills but no further details are given. ${ }^{4,10} \mathrm{Jim}$ Mckay observed a vireo which he knew was not a Blue-headed in the Centre Block of the Cypress Hills in early July 1999 at close range and in good light. He first thought the bird was a Plumbeous Vireo. Later when told there was no record of that species for Saskatchewan he decided he could not exclude the possibility that it might be a Cassin's Vireo (16 October 2003 letter from Jim McKay to Stuart Houston). A report of a "Solitary Vireo of the Rocky Mountain race" from the Inglewood Bird Sanctuary in Calgary on 16 August $1993^{6}$ is intriguing but inconclusive.

Without evidence of Plumbeous Vireos breeding in Saskatchewan we suggest that the vireo seen in 2004 was a spring transient that overflew its normal breeding range in the United States. This record is nearly $400 \mathrm{~km}$ north of the nearest known breeding range of the species in the mountains of southern Montana; this species also breeds in the Black Hills of South Dakota and Wyoming and in the mountains of extreme southern Idaho. ${ }^{2,5}$

The Cypress Hills could potentially support breeding populations of either Plumbeous or Cassin's vireos. Plumbeous Vireos typically breed in warm, dry, open structured mountain forests containing pine trees sometimes mixed with juniper
(Juniperus sp.), oak and aspen but do occur in riparian woodlands of cottonwoods, Manitoba Maple (Acer negundo) and willows. Cassin's Vireos typically breed in various cooler, wetter habitats including mixed riparian woodlands.2, 5 The nearest known breeding location for Cassin's Vireo is the southern Rocky Mountains of western Alberta where the birds often use spruce and pine stands intermixed with deciduous trees and shrubbery. ${ }^{8}$ During migration, the habitat used is more varied, including riparian areas and any tall vegetation. ${ }^{2}$ Heindel also states that in spring, Plumbeous Vireos migrate slightly later than Cassin's Vireos, perhaps because their breeding habitat in the interior Rockies is less hospitable early in the season than areas more to the west used by the Cassin's. ${ }^{5}$ Salt indicates that male Solitary (Blue-headed) Vireos arrive in central Alberta in midMay and females later in the month. ${ }^{7}$

Since the Plumbeous Vireo was given full species status by the AOU in 1997, we now need detailed records to help clarify the status of Blueheaded, Plumbeous and Cassin's vireos in southern Saskatchewan. Spring or summer observations of any of these three species of vireos in southern Saskatchewan would be welcomed by the senior author, especially if they pertain to birds suspected of breeding.

1. AMERICAN ORNITHOLOGISTS' UNION. 1997. $41^{\text {st }}$ supplement to the A. O. U. check-list of North American birds. Auk 114:542-552.

2. CURSON, D. R., and C.B. GOGUEN. 1998. Plumbeous Vireo (Vireo plumbeus). In The Birds of North America, No. 366. (A. Poole and F. Gill, eds.). Philadelphia, P. A. 20pp.

3. GODFREY, W. E. 1986. The Birds of Canada, Revised Edition. National Museums of Canada, Ottawa, Canada. 595pp.

4. GOLLOP, J. B. 1981. Prairie provinces region, summer report. 1981. American Birds 35:950-952. 
5. HEINDEL, M. T. 1996. Field Identification of the Solitary Vireo Complex. Birding, December, 1996:458-471.

6. KOES, R.F. and P. TAYLOR. 1993.The changing seasons, autumn 1992: prairie provinces region. American Birds 47:108-110.

7. SALT, W. R. 1973. Alberta Vireos and Wood Warblers. Provincial Museum and Archives of Alberta. Pub. No. 3. Queen's Printer, Edmonton, Alberta. $141 \mathrm{pp}$.
8. SEMENCHUK, G. P. 1992. The Atlas of Breeding Birds of Alberta. Federation of Alberta Naturalists. Edmonton, Alberta. $391 \mathrm{pp}$.

9. SIBLEY, D. A. 2000. The Sibley Guide to Birds. Knopf Publishers, New York. 544pp.

10. SMITH, A. R. 1996. Atlas of Saskatchewan Birds. Special Publication Number 22. Saskatchewan Natural History Society, Regina, Saskatchewan. 456pp.

11. WORMINGTON, A. 1997. Plumbeous Vireo: new to Ontario. Birders Journal 6:237-240.

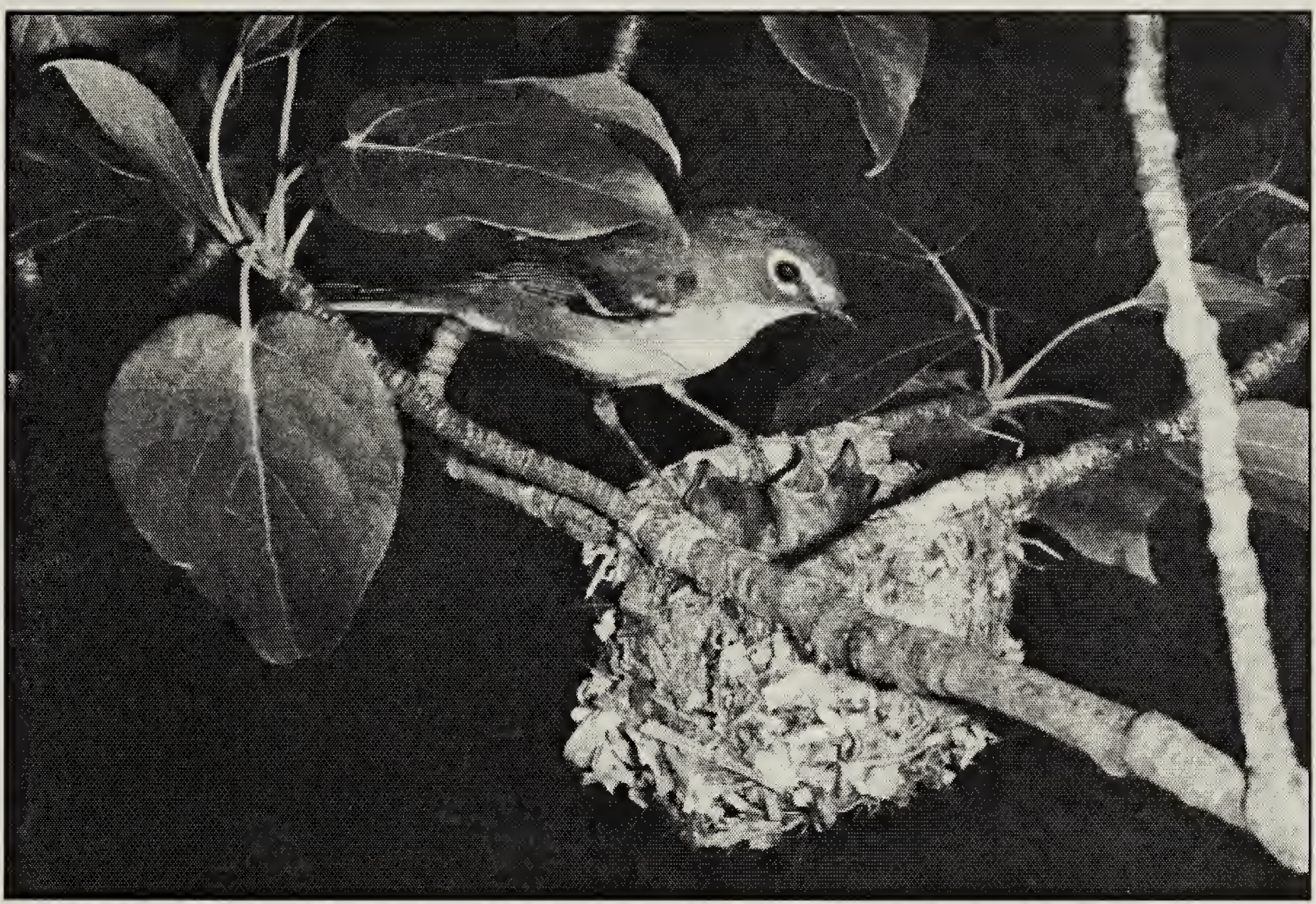

Blue-headed Vireo

R. E. Gehlert

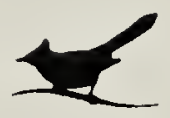

"In the winter woods, much is buried and hidden, but more is revealed....Two feet of fresh powder has already fallen on solidly frozen ground layered with fallen leaves. Recently, those leaves obscured the views through an otherwise opaque forest of green. Now, at the end of January, I could see through the forest from one large maple tree to another, to beech trees, tip-ups, and beyond to an open bog bordered with viburnum thickets. I was looking for bird nests that had in the summer been almost impossible to see because they were then enveloped in leaves. They would now show up as dark silhouettes with white caps."

Bernd Heinrich, Winter World, p. 62. 